episodes in clinic and non-clinic subjects. J Child Psychol Psychiatry 2006; 47: 927-34.

25 Goodyer IM, Herbert J, Altham PME, Pearson J, Secher S, Shiers S. Adrenal secretion during major depression in 8 to 16 year olds. I: Altered diurnal rhythms in salivary cortisol and dehydroepiandrosterone (DHEA) at presentation. Psychol Medicine 1996; 26: 245-56.

26 Guazzo EP, Kirkpatrick PJ, Goodyer IM, Shiers S, Herbert, J. Cortisol, dehydroepandrosterone (DHEA), and DHEA sulfate in the cerebrospinal fluid of man: relation to blood levels and the effects of age. J Clin Endocrinol Metab1996: 81: 3951-60.

27 Stata. STATA 10.0. 800-STATA-PC. Stata Corp, USA, 2006.

28 Netherton C, Goodyer IM, Tamplin A, Herbert J. Salivary cortisol and dehydroepiandrosterone in relation to puberty and gender. Psychoneuroendocrinology 2004; 29: 125-40.

29 Zalsman G, Huang YY, Oquendo MA, Burke AK, Hu XZ, Brent DA, et al. Association of a triallelic serotonin transporter gene promoter region (5-HTTLPR) polymorphism with stressful life events and severity of depression. Am J Psychiatry 2006; 163: 1588-93.

30 Hruschka DJ, Kohrt BA, Worthman CM. Estimating between- and withinindividual variation in cortisol levels using multilevel models.

Psychoneuroendocrinology 2005; 30: 698-714.

31 O'Hara R, Schroder C,M, Mahadevan R, Schatzberg AF, Lindley S, Fox S, et al. Serotonin transporter polymorphism, memory and hippocampal volume in the elderly: association and interaction with cortisol. Mol Psychiatry 2007; 12: $544-55$.
32 Lesch KP. Variation of serotonergic gene expression: neurodevelopment and the complexity of response to psychopharmacologic drugs. Eur Neuropsychopharmacol 2001; 11: 457-74.

33 Champoux M, Bennett A, Shannon C, Higley JD, Lesch KP, Suomi SJ. Serotonin transporter gene polymorphism, differential early rearing, and behavior in rhesus monkey neonates. Mol Psychiatry 2002; 7: 1058-63.

34 Jarrell H, Hoffman JB, Kaplan JR, Berga S, Kinkead B, Wilson ME. Polymorphisms in the serotonin reuptake transporter gene modify the consequences of social status on metabolic health in female rhesus monkeys. Physiol Behav 2008; 93: 807-19.

35 Weaver IC, Cervoni N, Champagne FA, D'Alessio AC, Sharma S, Seckl JR, et al. Epigenetic programming by maternal behavior. Nat Neurosci 2004; 7 847-54.

36 Bennett AJ, Lesch KP, Heils A, Long JC, Lorenz JG, Shoaf SE, et al. Early experience and serotonin transporter gene variation interact to influence primate CNS function. Mol Psychiatry 2002; 7: 118-22.

37 Herbert J, Goodyer IM, Grossman AB, Hastings MH, de Kloet ER, Lightman SL, et al. Do corticosteroids damage the brain? J Neuroendocrinol 2006; 18: 393-411.

38 Kim-Cohen J, Caspi A, Moffitt TE, Harrington H, Milne BJ, Poulton R. Prior juvenile diagnoses in adults with mental disorder: developmental follow-back of a prospective-longitudinal cohort. Arch Gen Psychiatry 2003; 60: 709-17.

\title{
extra
}

\section{Are you anti-psychiatry?}

\section{James Main}

One afternoon after passing finals, I was walking down the high street past the building in which we had taken our exams. I saw a placard positioned outside - 'alternative careers fair'. On impulse, I took a quick look around to ensure no one medically-inclined was in sight, and dipped inside.

In the limbo after 6 years of lectures, patients and essay crises, only houseman-hood loomed ahead. Perhaps this nudged me inside to glimpse what else might be out there! Of course, nothing that delivered the satisfaction of doctoring but bypassed weekend on-calls - TEFL or charity administration didn't appeal.

Then I found a rather different stall. The Citizens' Commission for Human Rights (CCHR) had a plush display with a laptop showing clips from a DVD. Curiosity drew me in. The laptop was screening a range of disturbing scenes, with a sinister accompanying soundtrack. The DVD cover pictured a roll of bank notes in a pool of blood. The title read: 'Psychiatry: An Industry of Death'. The hairs prickled on the back of my neck, but I was drawn to engage the middle-aged lady behind the table in conversation.

Our exchange covered some of the CCHR's concerns - 'child-drugging' (Ritalin for ADHD in America). I agreed there was probably some overzealous prescribing out there. ECT with no muscle relaxant - I explained to my new acquaintance (by now she knew I was a doctorto-be) that this was an historic practice and things are very different now in the UK though she didn't seem relieved by this.

Our unfolding discussion brought the strangest experience. The lady leaned over and asked with a warm smile and the expectant tone of making a like-minded ally, 'And are you anti-psychiatry?' I paused and considered my response. She was in high heels and I reckoned I could make the stairs a good deal faster than she, if things turned nasty.

'Umm - well - I don't think I can be anti-psychiatry, as I want to be a psychiatrist.' Her face fell. No like-minded friends were to be made that afternoon.

'Well,' she began, 'do you want to help people?' I hesitated - this sounded like the kind of trick question consultants ask you on ward rounds.

'Err - yes?'

'Well, that's a good start' she replied, clearly struggling with a polite young man who did not quite fit her box of 'human-rights-abusing-psychiatrist'.

Our parting was not disagreeable, but as I walked away, my heart was racing and I couldn't wait to get away. I had never felt so resented for occupying what seemed diplomatic middle ground. Only after I left did it occur to me that I had had to defend what I wanted to do with my life to a complete stranger with strong feelings against psychiatry.

The CCHR and its allied Church of Scientology as I later discovered are well known for their hostile attitude towards psychiatry, but my brief encounter highlighted for me the need to work reflectively and be able to justify our practice. I hope acquiring an understanding of other perspectives will go on helping me strengthen that middle ground where mutual understanding can alleviate sometimes irrational hostility and salvage therapeutic relationships. 